\title{
Using of Androgen Receptor Expression as a Novel Potential Biomarker in Predicting Survival of Women with Metastatic Triple Negative Breast
} Cancer

\section{Mirco Pistelli ${ }^{1 *}$, Alessandra Pagliacci ${ }^{1}$, Zelmira Ballatore ${ }^{1}$, Mariagrazia De Lisa ${ }^{1}$, Tommasina Biscotti ${ }^{2}$, Alfredo Santinelli ${ }^{2}$, Nicola Battelli ${ }^{1}$, Miriam Caramanti \\ 1, Elena Maccaroni', Raffaella Bracci ${ }^{1}$, Rossana Berardi' and Stefano Cascinu ${ }^{1}$}

${ }^{1}$ Clinica di Oncologia Medica, Università Politecnica delle Marche, AO Ospedali Riuniti-Ancona, Ancona, Italy

${ }^{2}$ Anatomia Patologica, AO Ospedali Riuniti-Ancona, Università Politecnica delle Marche, Ancona, Italy

\section{Abstract}

Background and objective: The androgen receptor $(A R)$ is a member of the steroid receptor subfamily with well-known biological and therapeutic importance in prostate cancer. There is evidence that the androgen signalling pathway may play a critical role also in normal and malignant breast tissue. They are highly expressed in triple negative breast cancer (TNBC) but it is not clear if AR expression is correlated with survival in advanced TNBC. Therefore, in the present study we investigated the prognostic value of AR expression in metastatic TNBC.

Patients and methods: Stage IV TNBC was included in the analysis. Patients with poor performance status (ECOG $>2$ ) were excluded. Tumors with $\geq 10 \%$ nuclear-stained cells were considered to be positive for AR. Univariate and multivariate analyses were performed.

Results: From a database of 208 TNBC patients, 24 cases of advanced TNBC were identified; out of 24 patients, $33 \%$ were AR positive. The median age at diagnosis was 61 years (range 30-78 years). All patients included in the study received first-line chemotherapy for their disease. Median progression free-survival (mPFS) and overall survival (OS) were 3.5 months (range 0.3-27.3 months) and 25.9 months (range 2.52-122.2 months), respectively. Univariate analysis showed that AR negative advanced TNBC had a significantly worse PFS (3.2 vs 7.9 months; $p=0.02 ; \mathrm{HR}=2.57,95 \% \mathrm{Cl} 1.15-10.53)$ and $\mathrm{OS}(20.5$ vs 47.4 months; $\mathrm{p}=0.01 ; \mathrm{HR}=2.88,95 \% \mathrm{Cl} 1.32-$ 9.43). Multivariate analysis confirms that AR expression was an independent prognostic factor of PFS ( $p=0.04$; $\mathrm{HR}=2.19,95 \% \mathrm{Cl} 1.52-5.91)$, as well as for $\mathrm{OS}(\mathrm{p}=0.05 ; \mathrm{HR}=2.21,95 \% \mathrm{Cl} 0.98-2.55)$.

Conclusions: Our preliminary results suggested that the assessment of AR expression may be a useful tool to identify patients with a good or a poor prognosis. Furthermore, since that about one third of metastatic TNBC expressed ARs, they may represent a target for novel potential treatment options in advanced TNBC.

Keywords: Androgen receptor; Triple negative; Breast cancer; Metastatic; Survival

\section{Introduction}

Triple negative breast cancers (TNBC), characterized by lack of expression (or minimal expression) of estrogen receptor (ER), progesterone receptor (PR) and an absence of human epidermal growth factor receptor-2 (HER-2) overexpression, are a clinical problem because they often present with higher rates of visceral metastases, a relatively shorter median survival of 7-13 months and have a limited duration of response to chemotherapy [1-6]. Although a variety of cytotoxic agents (administered as mono-chemotherapy or as combination) are available, none is recommended specifically for advanced TNBC, even if platinum-based therapy, taxanes, anthracyclines have shown promising activity in small neoadjuvant studies [7-11] and consequently may be rational choices for patients with metastatic disease. However, treatment choices are limited for patients with metastatic disease as many receive adjuvant therapy with anthracyclines, taxanes or cyclophosphamide for primary tumor treatment [12]. Furthermore daily clinical practice reveals the heterogeneity of TNBC. Most of women progress quickly on systemic therapy and have a poor survival, but some may have a slower progressive course. It may reflect an underlying biological diversity of TNBC, probably due to the activation of intracellular pathways that are related with tumor survival and proliferation. The androgen signalling pathway may play a critical role in normal and malignant breast tissue [13]. Although it has been indicated that ARs are expressed in a significant number of early TNBC and that they might play a role as a prognostic marker, to date we unknown if AR expression have a correlation with survival of patients with advanced TNBC [14]. Therefore, in the present study we investigated the prognostic value of AR expression in metastatic TNBC.

\section{Patients and Methods}

All consecutive patients with metastatic TNBC (stage IV) who received first-line chemotherapy at our Institution from January 2006 and December 2012 were included. Patients were eligible if they had histologically documented TNBC with recurrent disease after curative surgical resection or metastatic disease at diagnosis; measurable or evaluable metastatic advanced disease; Eastern Cooperative Oncology Group performance status $0-2$; age between 18 and 80 ; written

*Corresponding author: Mirco Pistelli, MD, Clinica di Oncologia Medica, Università Politecnica delle Marche, AO Ospedali Riuniti-Ancona, 60121 Ancona, Italy, Tel: +39 0715964611; E-mail: mirco.pistelli@alice.it

Received July 23, 2014; Accepted September 24, 2014; Published September 28, 2014

Citation: Pistelli M, Pagliacci A, Ballatore Z, De Lisa M, Biscotti T, et al. (2014) Using of Androgen Receptor Expression as a Novel Potential Biomarker in Predicting Survival of Women with Metastatic Triple Negative Breast Cancer. J Cancer Sci Ther 6: 388-393. doi:10.4172/1948-5956.1000297

Copyright: $\odot 2014$ Pistelli M, et al. This is an open-access article distributed under the terms of the Creative Commons Attribution License, which permits unrestricted use, distribution, and reproduction in any medium, provided the original author and source are credited. 
Citation: Pistelli M, Pagliacci A, Ballatore Z, De Lisa M, Biscotti T, et al. (2014) Using of Androgen Receptor Expression as a Novel Potential Biomarker in Predicting Survival of Women with Metastatic Triple Negative Breast Cancer. J Cancer Sci Ther 6: 388-393. doi:10.4172/19485956.1000297

informed consent; no evidence of central nervous system metastasis; adequate bone marrow and organ functions $\left(\mathrm{WBC}>4.000 / \mathrm{mm}^{3}\right.$ and or absolute neutrophil count (ANC) $>1.500 / \mathrm{mm}^{3}$; platelets $>100.000 /$ $\mathrm{mm}^{3}$; AST/ALT $<2.5$ times the upper normal limit (UNL) or $<5$ times the UNL if liver metastasis; bilirubin $<2 \mathrm{mg} / \mathrm{dl}$; creatinine $<1.5 \mathrm{mg} / \mathrm{dl}$ ).

\section{Immunohistochemistry}

Tissue samples were fixed in $10 \%$ buffered formalin and embedded in paraffin wax for routine histological examinations. The slides were stained with hematoxylin and eosin $(\mathrm{H} \& \mathrm{E})$ with additional immunostaining for ER (clone: SP1, dilution: 1:200; NeoMarkers, Fremont, CA, USA), PR (clone: SP2, dilution: 1:250; NeoMarkers, Fremont), Her2/neu (Herceptest, Dako, Carpinteria, CA, USA), CK 5/6 (1:100, M7237, Dako), Ki-67 (1:200, M7240, Dako), AR (1:60 F39.4.1, BioGenex), ALDH1 (Clone 44/ALDH, 1:200, Transduction Laboratories) and e-cadherin (clone NCH-38, 1:50 DAKO). ER, PR and $\mathrm{AR}$ were considered positive if there were at least $10 \%$ positive invasive tumor nuclei in the sample. HER-2 status was evaluated by immunohistochemistry (IHC) using a semiquantitative score $(0-$ $3+)$. Tumor staining was compared to the staining of normal breast epithelium from the same patient as a negative control. For clinical purposes, no staining or weak $(1+)$ and incomplete membrans' staining were considered a negative result. Patients with $2+$ IHC staining for HER2 underwent fluorescence in-situ hybridization to confirm HER2 positivity. Triple-negative status (ER negative, PR negative and HER2 negative) was finally diagnosed and re-reviewed by the single study pathologist of our Institution. Carcinoma cells with cytoplasmic staining were considered to be ALDH1-positive cells. Any proportion of ALDH1-positive carcinoma cells was considered to represent epithelial ALDH1 expression. Positivity for CK5/6 was defined as cytoplasmic staining in more than $10 \%$ of carcinoma cells. E-cadherin expression was semi-quantitative analyzed according to the percentage of cells showing membrane positivity: 0,0 to $10 \% ; 1+, 10$ to $30 \% ; 2+30$ to $70 \% ; 3+>70 \%$. E-cadherin expression was considered positive when scores were $\geq 2$ and negative when scores were $\leq 1$.

\section{Statistical analysis}

Progression-free survival (PFS) was calculated from the first day of first-line chemotherapy until the time of the first occurrence of progression, death from any cause or to the date of last follow-up if none of the preceding events had occurred. Overall survival (OS) was defined as the interval between the date of diagnosis of TNBC to death or last follow-up visit. Patients who were not reported to be deceased at the time of the analysis were censored at the date they were last known to be alive. Survival distribution was estimated by the Kaplan Meier method. The Cox multivariate proportional hazard regression model was used to evaluate the effects of the prognostic factors on survival. Significant differences in probability of surviving between the strata were evaluated by log-rank test. Hazard ratios and $95 \%$ confidence intervals (CIs) were estimated from regression coefficients. A significance level of 0.05 was chosen to assess the statistical significance. Statistical analysis was performed with MedCalc package (MedCalc v9.4.2.0 Software).

\section{Results}

\section{Patients characteristics}

From a database of 208 TNBC patients, 24 cases of advanced TNBC were identified. The median age was 61 years (range $30-78$ years). The majority of them $(70.8 \%)$ had a menopausal status. Out of 24 TNBC, 20 (83\%) were histologically identified as invasive ductal carcinomas. The median value of Ki-67 was $60 \%$ (range 19 to $95 \%$ ). Lympho-vascular invasion and necrosis were documented in $37.5 \%$ and $20.8 \%$ of tumors at diagnosis, respectively. All patients had metastatic disease at study entry; $79 \%$ of them had a visceral disease. First-line chemotherapy regimens are listed in Table 1 . At the time of analysis $75 \%$ of patients showed progressive disease after first-line-chemotherapy and $43 \%$ of them received second-line chemotherapy. The median PFS and OS were 3.5 months (range 0.3-27.3 months) and 25.9 months (range 2.52122.2 months), respectively. To date, 4 patients are still alive.

Out of 24 patients, 8 (33\%) showed positive immunostaining for AR, while 10 (41.6\%) and $9(37.5 \%)$ patients were positive for ALDH1 and CK $5 / 6$, respectively. E-cadherin was positive in the major part of them (75\%). Clinical and histological characteristic of enrolled patients are summarized in Table 1.

\begin{tabular}{|c|c|c|}
\hline Variable & No of patients & $\%$ of total \\
\hline $\begin{array}{l}\text { Age, years (median, } 61 \text { years) } \\
\leq 60 \\
>60\end{array}$ & $\begin{array}{l}11 \\
13\end{array}$ & $\begin{array}{l}45.8 \% \\
54.2 \%\end{array}$ \\
\hline $\begin{array}{l}\text { Performance status } \\
\text { ECOG } 0 \\
\text { ECOG 1-2 }\end{array}$ & $\begin{array}{c}20 \\
5\end{array}$ & $\begin{array}{l}83.4 \% \\
16.6 \%\end{array}$ \\
\hline $\begin{array}{l}\text { Menopausal status } \\
\text { Pre- } \\
\text { Post- }\end{array}$ & $\begin{array}{c}7 \\
17\end{array}$ & $\begin{array}{l}29.2 \% \\
70.8 \%\end{array}$ \\
\hline $\begin{array}{l}\text { Tumour histology } \\
\text { Ductal carcinoma } \\
\text { Lobular carcinoma } \\
\text { Other }\end{array}$ & $\begin{array}{c}20 \\
2 \\
2\end{array}$ & $\begin{array}{c}83.4 \% \\
8.3 \% \\
8.3 \%\end{array}$ \\
\hline $\begin{array}{l}\text { Histologic grade } \\
\text { G1-G2 } \\
\text { G3 }\end{array}$ & $\begin{array}{c}6 \\
18\end{array}$ & $\begin{array}{l}25 \% \\
75 \%\end{array}$ \\
\hline $\begin{array}{l}\text { Ki-67 (median } 60 \%) \\
\leq 20 \% \\
>20 \%\end{array}$ & $\begin{array}{c}7 \\
17\end{array}$ & $\begin{array}{l}29.2 \% \\
70.8 \%\end{array}$ \\
\hline $\begin{array}{l}\text { Lympho-vascular invasion } \\
\text { Yes } \\
\text { No }\end{array}$ & $\begin{array}{c}9 \\
15\end{array}$ & $\begin{array}{l}37.5 \% \\
62.5 \%\end{array}$ \\
\hline $\begin{array}{l}\text { Necrosis } \\
\text { Yes } \\
\text { No }\end{array}$ & $\begin{array}{c}5 \\
19\end{array}$ & $\begin{array}{l}20.8 \% \\
79.2 \%\end{array}$ \\
\hline $\begin{array}{l}\text { AR } \\
\text { Positive } \\
\text { Negative }\end{array}$ & $\begin{array}{c}8 \\
16\end{array}$ & $\begin{array}{c}33 \% \\
67 \%\end{array}$ \\
\hline $\begin{array}{l}\text { Type of surgery } \\
\text { Quadrantectomy } \\
\text { Radical mastectomy }\end{array}$ & $\begin{array}{l}10 \\
14\end{array}$ & $\begin{array}{l}41.7 \% \\
58.3 \%\end{array}$ \\
\hline $\begin{array}{l}\text { (Neo)adjuvant chemotherapy } \\
\text { CMF/CMFLike } \\
\text { Antracyclines } \\
\text { Antracyclines and taxanes } \\
\text { No }\end{array}$ & $\begin{array}{c}5 \\
8 \\
10 \\
1\end{array}$ & $\begin{array}{c}20.8 \% \\
33 \% \\
41.7 \% \\
4.5 \%\end{array}$ \\
\hline $\begin{array}{l}\text { Visceral disease } \\
\text { Yes } \\
\text { No }\end{array}$ & $\begin{array}{c}19 \\
5\end{array}$ & $\begin{array}{c}7.2 \% \\
20.8 \%\end{array}$ \\
\hline $\begin{array}{l}\text { Number of metastatic sites } \\
<3 \\
\geq 3\end{array}$ & $\begin{array}{c}16 \\
8\end{array}$ & $\begin{array}{l}67 \% \\
33 \%\end{array}$ \\
\hline $\begin{array}{l}\text { First-line chemotherapy } \\
\text { Antracyclines-based } \\
\text { Taxanes-based } \\
\text { Platinum-based } \\
\text { Other }\end{array}$ & $\begin{array}{c}5 \\
12 \\
6 \\
6\end{array}$ & $\begin{array}{l}20.8 \% \\
50 \% \\
33 \% \\
33 \%\end{array}$ \\
\hline $\begin{array}{l}\text { First-line chemotherapy } \\
\text { Single-agent } \\
\text { Combination of drugs }\end{array}$ & $\begin{array}{l}10 \\
14\end{array}$ & $\begin{array}{l}41.7 \% \\
58.3 \%\end{array}$ \\
\hline
\end{tabular}

Table 1: Baseline characteristics of 24 patients. 
Citation: Pistelli M, Pagliacci A, Ballatore Z, De Lisa M, Biscotti T, et al. (2014) Using of Androgen Receptor Expression as a Novel Potential Biomarker in Predicting Survival of Women with Metastatic Triple Negative Breast Cancer. J Cancer Sci Ther 6: 388-393. doi:10.4172/19485956.1000297

\section{Univariate analysis}

Univariate analysis showed that significant risk factors for reduced PFS were: age $<60$ years $(p=0.01), K i-67>20 \%(p=0.005$; Figure 1), presence of lympho-vascular invasion $(\mathrm{p}=0.02)$, negative immunostaining for AR ( $\mathrm{p}=0.02$; Figure 2$)$. A worsened OS was correlated to younger age $(<60$ years $)(\mathrm{p}=0.001)$, higher Ki-67 $(>20 \%)(\mathrm{p}=0.0009$; Figure 1), presence of lympho-vascular invasion $(\mathrm{p}=0.04)$ or visceral disease $(\mathrm{p}=0.006)$, negative immunostaining for AR ( $\mathrm{p}=0.01$; Figure 2). Types of first-line chemotherapy, necrosis, positive immunostaining for e-cadherin, aldh 1 and/or CK 5/6 were not statistically significantly related to survival (Table 2 ).

\section{Multivariate analysis}

Multivariate analysis confirms that $\mathrm{AR}$ expression was an independent prognostic factor of PFS ( $\mathrm{p}=0.04$; HR=2.19, 95\% CI 1.52 5.91) which was significantly better for AR positive advanced TNBC (7.9 vs 3.2 months) as well as for OS ( $\mathrm{p}=0.05$; HR=2.21, 95\% CI 0.98 2.55). Higher Ki-67 expression ( $>20 \%)$ was also related to worsened PFS ( $\mathrm{p}=0.04 ; \mathrm{HR}=2.38,95 \%$ CI 1.11-5.62) and OS ( $\mathrm{p}=0.02 ; \mathrm{HR}=2.37$, 95\% CI 1.11-5.07) of metastatic TNBC. No statistically significant results were reported for age, lympho-vascular invasion and presence of visceral disease (Table 3 ).

\section{Discussion}

The development and progression of breast cancers area highly dependent on the action of steroid hormones. However while estrogens can promote the growth of breast cancer has been clearly shown, the role of androgens is less clear. They can directly stimulate the growth of human breast cancer cell lines [15] and it has been reported that high levels of both testosterone and estradiol in serum precede breast cancer in postmenopausal women [16-18]. Nevertheless the role of AR in TNBC is still unclear, with some studies reporting a favourable effect with an improved survival [19-24], or a negative effect with a worse survival [25], or substantially no effect [26-31].

Based on these considerations, we investigated AR expression and their prognostic effect in metastatic TNBC patients. Our analysis revealed that one third of advanced TNBC patients had positive immunostaining for AR. This is similar to what commonly reported in other studies, where the proportion of AR positive TNBC ranges from 0 to 53\% [19-35]. In our study multivariate analysis showed that AR expression was an independent prognostic factor of PFS which was significantly better for AR positive advanced TNBC (7.9 vs 3.2 months; $\mathrm{p}=0.04$ ) as well as for OS (47.4 vs 20.5 months; $\mathrm{p}=0.05$ ).

While the majority of cell line studies suggest that androgen increase proliferation, cell line transfection experiments and survival analyses of histological samples suggest that the presence of AR in tumour may be either benign or predictive of better survival. A possible biological explanation is the progressive lack of $\mathrm{AR}$ expression in different stages of TNBC progression. Hanley et al. reported that in high grade TNBC cases, the lack of AR in carcinoma cells could facilitate the transition
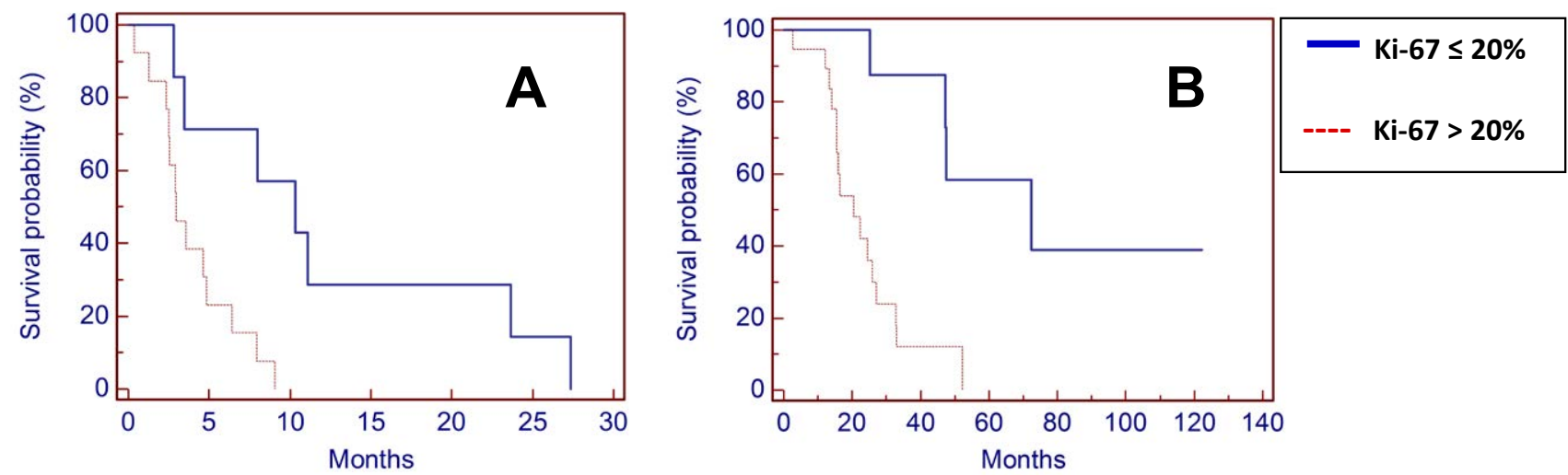

Figure 1: Progression free-survival $(A)$ and overall survival $(B)$ of patients with advanced triple negative breast cancer based on $\mathrm{Ki}-67$ expression $(\leq 20 \%$ vs $>20 \%$ ).
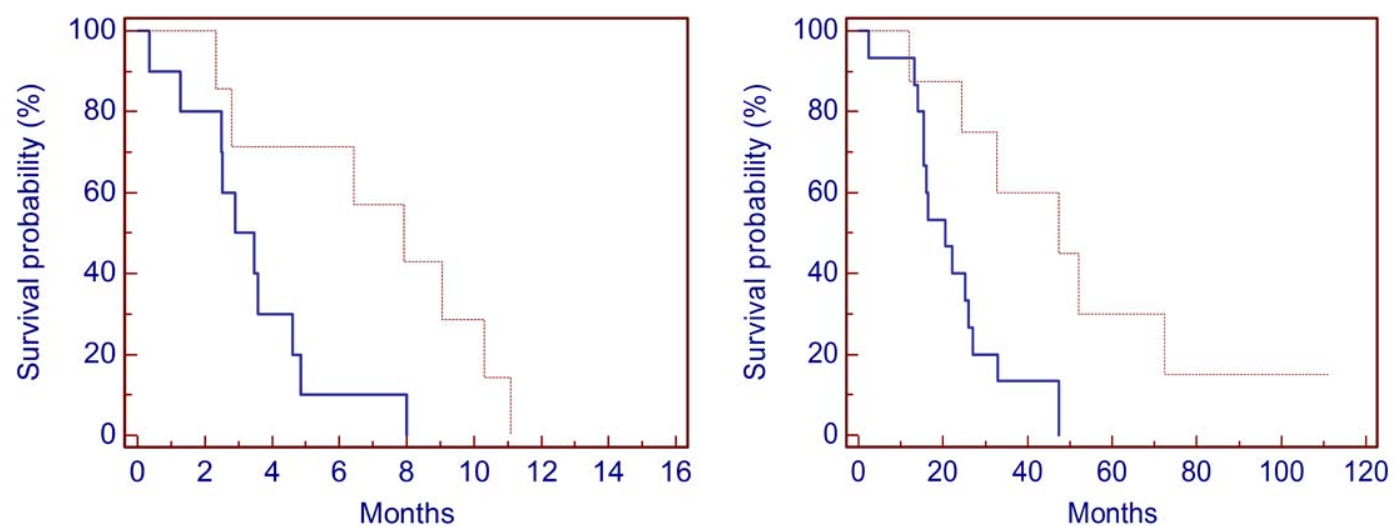

Figure 2: Progression free-survival (C) and overall survival (D) of patients with advanced triple negative breast cancer based on AR expression (positive vs negative). 
Citation: Pistelli M, Pagliacci A, Ballatore Z, De Lisa M, Biscotti T, et al. (2014) Using of Androgen Receptor Expression as a Novel Potential Biomarker in Predicting Survival of Women with Metastatic Triple Negative Breast Cancer. J Cancer Sci Ther 6: 388-393. doi:10.4172/19485956.1000297

\begin{tabular}{|c|c|c|c|c|c|c|}
\hline \multirow{2}{*}{ Parameters } & \multicolumn{3}{|c|}{ Univariate analysis } & \multicolumn{3}{|c|}{ Multivariate analysis } \\
\hline & HR & $95 \% \mathrm{Cl}$ & p-value & HR & $95 \% \mathrm{Cl}$ & p-value \\
\hline $\begin{array}{l}\text { Age, years } \\
\leq 60 \text { vs }>60\end{array}$ & 2.60 & $1.3-12.82$ & 0.01 & 0.26 & $0.03-2.24$ & 0.22 \\
\hline $\begin{array}{l}\text { Type of first line-chemotherapy } \\
\text { Single agent vs combination } \\
\text { Antracyclines vs Taxanes vs other }\end{array}$ & $\begin{array}{l}0.87 \\
0.68\end{array}$ & $\begin{array}{l}0.32-2.34 \\
0.76-3.63\end{array}$ & $\begin{array}{l}0.7 \\
0.08\end{array}$ & - & & \\
\hline $\begin{array}{l}\text { Ki- } 67 \\
\leq 20 \% \text { vs }>20 \%\end{array}$ & 2.33 & $1.08-4.65$ & 0.005 & 2.38 & $1.11-5.62$ & 0.04 \\
\hline $\begin{array}{l}\text { Necrosis } \\
\text { negative vs positive }\end{array}$ & 0.39 & $0.04-1.13$ & 0.07 & - & & \\
\hline $\begin{array}{l}\text { Lympho-vascular invasion } \\
\text { negative vs positive }\end{array}$ & 0.40 & $0.08-0.85$ & 0.02 & 0.24 & $0.02-2.58$ & 0.24 \\
\hline $\begin{array}{l}\text { Visceral disease } \\
\text { yes vs not }\end{array}$ & 0.48 & $0.16-1.19$ & 0.10 & - & & \\
\hline $\begin{array}{l}\text { e-cadherin } \\
\text { negative vs positive }\end{array}$ & 0.38 & $0.13-1.37$ & 0.15 & - & & \\
\hline $\begin{array}{l}\text { Aldh1 } \\
\text { negative vs positive }\end{array}$ & 0.73 & $0.25-1.98$ & 0.5 & - & & \\
\hline $\begin{array}{l}\text { CK5/6 } \\
\text { negative vs positive }\end{array}$ & 0.54 & $0.15-1.45$ & 0.19 & - & & \\
\hline $\begin{array}{l}\text { AR } \\
\text { negative vs positive }\end{array}$ & 2.57 & $1.15-10.53$ & 0.02 & 2.19 & $1.52-5.91$ & 0.04 \\
\hline
\end{tabular}

Table 2: Univariate and multivariate Cox regression analysis of factors associated with progression-free survival in advanced triple negative breast cancer.

\begin{tabular}{|c|c|c|c|c|c|c|}
\hline \multirow{2}{*}{ Parameters } & \multicolumn{3}{|c|}{ Univariate analysis } & \multicolumn{3}{|c|}{ Multivariate analysis } \\
\hline & HR & $95 \% \mathrm{Cl}$ & p-value & HR & $95 \% \mathrm{Cl}$ & p-value \\
\hline $\begin{array}{l}\text { Age, years } \\
\leq 60 \text { vs }>60\end{array}$ & 3.84 & $2.06-22.7$ & 0.001 & 0.46 & $0.09-2.17$ & 0.32 \\
\hline $\begin{array}{l}\text { Type of first line-chemotherapy } \\
\text { Single agent vs combination } \\
\text { Antracyclines vs Taxanes vs other }\end{array}$ & $\begin{array}{l}1.39 \\
0.85\end{array}$ & $\begin{array}{l}0.57-3.43 \\
0.39-6.71\end{array}$ & $\begin{array}{c}0.4 \\
0.93\end{array}$ & - & & \\
\hline $\begin{array}{l}\text { Ki- } 67 \\
\leq 20 \% \text { vs }>20 \%\end{array}$ & 2.21 & $1.37-6.51$ & 0.0009 & 2.37 & $1.11-5.07$ & 0.02 \\
\hline $\begin{array}{l}\text { Necrosis } \\
\text { negative vs positive }\end{array}$ & 0.70 & $0.2-2.07$ & 0.47 & - & & \\
\hline $\begin{array}{l}\text { Lympho-vascular invasion } \\
\text { negative vs positive }\end{array}$ & 0.42 & $0.12-0.97$ & 0.04 & 1.19 & $0.31-4.55$ & 0.79 \\
\hline $\begin{array}{l}\text { Visceral disease } \\
\text { yes vs not }\end{array}$ & 0.17 & $0.11-0.69$ & 0.006 & 3.84 & $0.7-21.15$ & 0.12 \\
\hline $\begin{array}{l}\text { e-cadherin } \\
\text { negative vs positive }\end{array}$ & 0.50 & $0.20-1.38$ & 0.19 & - & & \\
\hline $\begin{array}{l}\text { Aldh1 } \\
\text { negative vs positive }\end{array}$ & 0.77 & $0.29-1.93$ & 0.55 & - & & \\
\hline $\begin{array}{l}\text { CK5 or CK } 17 \\
\text { negative vs positive }\end{array}$ & 0.57 & $0.19-1.44$ & 0.21 & - & & \\
\hline $\begin{array}{l}\text { AR } \\
\text { negative vs positive }\end{array}$ & 2.88 & $1.32-9.43$ & 0.01 & 2.21 & $0.98-2.55$ & 0.05 \\
\hline
\end{tabular}

Table 3: Univariate and multivariate Cox regression analysis of factors associated with overall-survival in advanced triple negative breast cancer.

from in situ to invasive carcinoma and the same trend was not detected in low grade TNBC [36]. Similar results have been recently reported by McGhan LJ et al. [37]. They found AR expression decreased with progression from ductal-carcinoma in situ (DCIS) to invasive TNBC. Moreover, Thike et al. showed a significantly better disease freesurvival in AR positive TNBC with a trend for improved OS, suggesting that loss of $\mathrm{AR}$ is predictive of early recurrence and worse prognosis in TNBC [38]. The biological mechanism is still unclear but it has been postulated that androgen signalling may be related to tumor cell proliferation. McNamara et al. [39] analysed the relationship between the status of $A R$ and androgen synthesizing enzymes (5- $\alpha$ reductase type 1 and $17 \beta$-hydroxysteroid dehydrogenase type 5) in order to further understand androgenic actions. AR expression and enzyme positive cases were regarded to be associated with a significantly lower Ki-67 labelling index. They suggested that the presence of androgen synthesizing pathway in addition to AR expression in tumor cells may confer a better clinical outcome through suppression of cell proliferation. Ki-67 seems to have a key role in biological behaviour of TNBC and may represent one of the most important variable influencing prognosis of this kind of breast tumors. Our study remarks the correlation between Ki-67 and survival of TNBC; this is similar to what has been already observed in other previously studies where higher tumor cell proliferation was related to a worsened survival in TNBC patients [40].

Currently, there are no available targeted therapies for women with triple-negative disease. However, there are therapeutic targets of AR. Given that one-third of triple-negative breast cancers are AR-positive, this represents a potential opportunity for novel targeted treatment for these women. Bicalutamide is a nonsteroidal antiandrogen therapy used to treat metastatic prostate cancer. Recently results of a phase II trial of bicalutamide in patients with AR-positive, ER-negative metastatic 
Citation: Pistelli M, Pagliacci A, Ballatore Z, De Lisa M, Biscotti T, et al. (2014) Using of Androgen Receptor Expression as a Novel Potential Biomarker in Predicting Survival of Women with Metastatic Triple Negative Breast Cancer. J Cancer Sci Ther 6: 388-393. doi:10.4172/19485956.1000297

breast cancer showed $19 \%$ of clinical benefit rate and 12 weeks of median PFS; consequently bicalutamide showed proof of principle for the efficacy but further evaluations need to establish its hypothetical role in the treatment of this selected group of patients [41].

\section{Conclusion}

Our preliminary results revealed that AR expression is differently related to biological behaviour of advanced TNBC. In clinical practice this biomarker may be a useful tool to identify patients with a poor prognosis and for whom benefits of first-line chemotherapy were relatively lower. This finding could provide important information as to the potential roles of androgen effect through AR in development or progression of TNBC but further translational investigations regarding the mechanisms of androgen action in TNBC are required. Conversely, finding that about one third of advanced TNBC expressed ARs may support novel potential treatment options for advanced TNBC.

\section{References}

1. Foulkes WD, Smith IE, Reis-Filho JS (2010) Triple-negative breast cancer. N Engl J Med 363: 1938-1948.

2. Irvin WJ Jr, Carey LA (2008) What is triple-negative breast cancer? Eur J Cancer 44: 2799-2805

3. Oakman C, Viale G, Di Leo A (2010) Management of triple negative breast cancer. Breast 19: 312-321.

4. Pal SK, Childs BH, Pegram M (2011) Triple negative breast cancer: unmet medical needs. Breast Cancer Res Treat 125: 627-636.

5. Dent R, Trudeau M, Pritchard KI, Hanna WM, Kahn HK, et al. (2007) Triplenegative breast cancer: clinical features and patterns of recurrence. Clin Cancer Res 13: 4429-4434.

6. Anders CK, Carey LA (2009) Biology, metastatic patterns, and treatment of patients with triple-negative breast cancer. Clin Breast Cancer 9 Suppl 2: S7381.

7. Carey LA, Dees EC, Sawyer L, Gatti L, Moore DT, et al. (2007) The triple negative paradox: primary tumor chemosensitivity of breast cancer subtypes. Clin Cancer Res 13: 2329-2334

8. Silver DP, Richardson AL, Eklund AC, Wang ZC, Szallasi Z, et al. (2010) Efficacy of neoadjuvant Cisplatin in triple-negative breast cancer. J Clin Oncol 28: $1145-1153$.

9. Byrski T, Gronwald J, Huzarski T, Grzybowska E, Budryk M, et al. (2010) Pathologic complete response rates in young women with BRCA1-positive breast cancers after neoadjuvant chemotherapy. J Clin Oncol 28: 375-379.

10. Sirohi B, Arnedos M, Popat S, Ashley S, Nerurkar A, et al. (2008) Platinumbased chemotherapy in triple-negative breast cancer. Ann Oncol 19: 18471852.

11. Liedtke C, Mazouni C, Hess KR, André F, Tordai A, et al. (2008) Response to neoadjuvant therapy and long-term survival in patients with triple-negative breast cancer. J Clin Oncol 26: 1275-1281

12. Isakoff SJ (2010) Triple-negative breast cancer: role of specific chemotherapy agents. Cancer J 16: 53-61.

13. Peters AA, Buchanan G, Ricciardelli C, Bianco-Miotto T, Centenera MM, et al. (2009) Androgen receptor inhibits estrogen receptor-alpha activity and is prognostic in breast cancer. Cancer Res 69: 6131-6140.

14. McNamara KM, Yoda T, Takagi K, Miki Y, Suzuki T, et al. (2013) Androgen receptor in triple negative breast cancer. J Steroid Biochem Mol Biol 133: 66 76.

15. Lippman M, Bolan G, Huff K (1976) The effects of androgens and antiandrogens on hormone-responsive human breast cancer in long-term tissue culture. Cancer Res 36: 4610-4618.

16. Berrino F, Muti P, Micheli A, Bolelli G, Krogh V, et al. (1996) Serum sex hormone levels after menopause and subsequent breast cancer. J Natl Cancer Inst 88: 291-296.

17. Key T, Appleby P, Barnes I, Reeves G; Endogenous Hormones and Breas
Cancer Collaborative Group (2002) Endogenous sex hormones and breast cancer in postmenopausal women: reanalysis of nine prospective studies. $J$ Natl Cancer Inst 94: 606-616.

18. Sieri S, Krogh V, Bolelli G, Abagnato CA, Grioni S, et al. (2009) Sex hormone levels, breast cancer risk, and cancer receptor status in postmenopausal women: the ORDET cohort. Cancer Epidemiol Biomarkers Prev 18: 169-176.

19. Agoff SN, Swanson PE, Linden H, Hawes SE, Lawton TJ (2003) Androgen receptor expression in estrogen receptor-negative breast cancer Immunohistochemical, clinical, and prognostic associations. Am J Clin Patho 120: 725-731.

20. Rakha EA, El-Sayed ME, Green AR, Lee AH, Robertson JF, et al. (2007) Prognostic markers in triple-negative breast cancer. Cancer 109: 25-32.

21. Luo X, Shi YX, Li ZM, Jiang WQ (2010) Expression and clinical significance of androgen receptor in triple negative breast cancer. Chin J Cancer 29: 585-590.

22. Loibl S, Müller BM, von Minckwitz G, Schwabe M, Roller M, et al. (2011) Androgen receptor expression in primary breast cancer and its predictive and prognostic value in patients treated with neoadjuvant chemotherapy. Breast Cancer Res Treat 130: 477-487.

23. Tang D, Xu S, Zhang Q, Zhao W (2012) The expression and clinical significance of the androgen receptor and E-cadherin in triple-negative breast cancer. Med Oncol 29: 526-533.

24. He J, Peng R, Yuan Z, Wang S, Peng J, et al. (2012) Prognostic value of androgen receptor expression in operable triple-negative breast cancer: a retrospective analysis based on a tissue microarray. Med Oncol 29: 406-410.

25. Hu R, Dawood S, Holmes MD, Collins LC, Schnitt SJ, et al. (2011) Androgen receptor expression and breast cancer survival in postmenopausal women. Clin Cancer Res 17: 1867-1874.

26. Park S, Koo J, Park HS, Kim JH, Choi SY, et al. (2010) Expression of androgen receptors in primary breast cancer. Ann Oncol 21: 488-492.

27. Park S, Koo JS, Kim MS, Park HS, Lee JS, et al. (2011) Androgen receptor expression is significantly associated with better outcomes in estrogen receptor-positive breast cancers. Ann Oncol 22: 1755-1762.

28. Micello D, Marando A, Sahnane N, Riva C, Capella C, et al. (2010) Androgen receptor is frequently expressed in HER2-positive, ER/PR-negative breast cancers. Virchows Arch 457: 467-476.

29. Gonzalez-Angulo AM, Stemke-Hale K, Palla SL, Carey M, Agarwal R, et al. (2009) Androgen receptor levels and association with PIK3CA mutations and prognosis in breast cancer. Clin Cancer Res 15: 2472-2478.

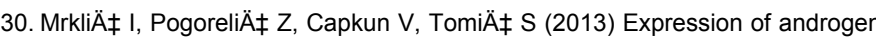
receptors in triple negative breast carcinomas. Acta Histochem 115: 344-348.

31. Pistelli M, Caramanti M, Biscotti T, Santinelli A, Pagliacci A, et al. (2014) Androgen receptor expression in early triple-negative breast cancer: clinical significance and prognostic associations. Cancers (Basel) 6: 1351-1362.

32. Meijnen P, Peterse JL, Antonini N, Rutgers EJ, van de Vijver MJ (2008) Immunohistochemical categorisation of ductal carcinoma in situ of the breast. Br J Cancer 98: 137-142.

33. Niemeier LA, Dabbs DJ, Beriwal S, Striebel JM, Bhargava R (2010) Androgen receptor in breast cancer: expression in estrogen receptor-positive tumors and in estrogen receptor-negative tumors with apocrine differentiation, Mod Pathol 23: $205-212$.

34. Qi JP, Yang YL, Zhu H, Wang J, Jia Y, et al. (2012) Expression of the androgen receptor and its correlation with molecular subtypes in 980 chinese breast cancer patients. Breast Cancer (Auckl) 6: 1-8.

35. Tsutsumi $Y$ (2012) Apocrine carcinoma as triple-negative breast cancer: nove definition of apocrine-type carcinoma as estrogen/progesterone receptor negative and androgen receptor-positive invasive ductal carcinoma. Jpn J Clin Oncol 42: 375-386

36. Hanley K, Wang J, Bourne P, Yang Q, Gao AC, et al. (2008) Lack of expression of androgen receptor may play a critical role in transformation from in situ to invasive basal subtype of high-grade ductal carcinoma of the breast. Hum Pathol 39: 386-392.

37. McGhan LJ, McCullough AE, Protheroe CA, Dueck AC, Lee JJ, et al. (2014) Androgen receptor-positive triple negative breast cancer: a unique breast cancer subtype. Ann Surg Oncol 21: 361-367. 
Citation: Pistelli M, Pagliacci A, Ballatore Z, De Lisa M, Biscotti T, et al. (2014) Using of Androgen Receptor Expression as a Novel Potential Biomarker in Predicting Survival of Women with Metastatic Triple Negative Breast Cancer. J Cancer Sci Ther 6: 388-393. doi:10.4172/19485956.1000297

38. Thike AA, Yong-Zheng Chong L, Cheok PY2, Li HH3, Wai-Cheong Yip G3, et al. (2014) Loss of androgen receptor expression predicts early recurrence in triple-negative and basal-like breast cancer. Mod Pathol 27: 352-360.

39. McNamara KM, Yoda T, Miki Y, Chanplakorn N, Wongwaisayawan S, et al. (2013) Androgenic pathway in triple negative invasive ductal tumors: its correlation with tumor cell proliferation. Cancer Sci 104: 639-646.
40. Kashiwagi S, Yashiro M, Takashima T, Aomatsu N, Ikeda K, et al. (2011) Advantages of adjuvant chemotherapy for patients with triple-negative breast cancer at Stage II: usefulness of prognostic markers E-cadherin and Ki67. Breast Cancer Res 13: R122.

41. Gucalp A, Tolaney S, Isakoff SJ, Ingle JN, Liu MC, et al. (2013) Phase II trial of bicalutamide in patients with androgen receptor-positive, estrogen receptornegative metastatic Breast Cancer. Clin Cancer Res 19: 5505-5512. 